\title{
ANALISIS KARAKTERISTIK HIDROGEOKIMIA AIRTANAH DI PULAU KORAL PANGGANG, KEPULAUAN SERIBU, DKI JAKARTA
}

\author{
Ahmad Cahyadi ${ }^{1}$, Wahyu Hidayat ${ }^{1}$ \\ 1Departemen Geografi Lingkungan, Fakultas Geografi, Universitas Gadjah Mada \\ Bulaksumur, Depok, Sleman, D.I. Yogyakarta 55821 \\ Email: ahmadcahyadi@geo.ugm.ac.id
}

\begin{abstract}
Abstrak
Pulau kecil memiliki karakteristik hidrologi yang sangat unik. Karakter unik tersebut di antaranya curah hujan yang rendah, tangkapan hujan yang sempit dan kerawanan tinggi terhadap intrusi air laut. Penelitian ini bertujuan untuk (1) menganalisis tipe atau fasies hidrogeokimia airtanah di Pulau Koral Panggang dan (2) menganalisis evolusi hidrogeokimia airtanah di Pulau Koral Panggang. Data yang digunakan meliputi hasil analisis unsur mayor dari sampel airtanah yang di ambil dari lokasi kajian. Analisis tipe kimia ditentukan dengan analisis diagram stiff, sedangkan analisis evolusi hidrogeokimia dilakukan dengan analisis diagram piper. Tipe air atau fasies hidrokimia airtanah di Pulau Koral Panggang adalah $\mathrm{MgCl}_{2}$, dengan evolusi hidrokimia dari $\mathrm{CaCO}_{3}$ menjadi $\mathrm{MgCl}_{2}$. Perubahan yang terjadi menunjukkan perubahan tipe air yang disebabkan oleh intrusi air laut.
\end{abstract}

Kata Kunci: Pulau Kecil, Pulau Koral Panggang, Airtanah, Hidrogeokimia

\begin{abstract}
The small island has a very unique hydrological characteristics. The unique character are low rainfall, rain catchment narrow and high vulnerability to seawater intrusion. This study aims to (1) analyze the groundwater hydrogeochemistry facies in Panggang Cay and (2) to analyze the evolution of groundwater hydrogeochemistry in Panggang Cay. Data used include major element analysis results of the groundwater samples taken from the study site. Hidrogeochemistry fasies of groundwater determined the type of diagram analysis stiff, while the analysis of the hydrogeochemistry evolution of groundater analyzed using piper diagram. Groundwater hydrochemical facies in Panggang Cay is $\mathrm{MgCl}_{2}$ with hydrogeochemical evolution of $\mathrm{CaCO}_{3}$ into $\mathrm{MgCl}_{2}$. The evolution of hydrogeochemistry fasies that occur indicate the sea water intrusion process.
\end{abstract}

Keywords: Small Island, Panggang Cay, Grounwater, Hydrogeochemistry

\section{PENDAHULUAN}

Airtanah merupakan salah satu komponen yang penting dalam siklus hidrologi di bagian bawah permukaan tanah (Sen, 2015). Airtanah disimpan di bawah permukaan tanah pada ruang pori antar butir, retakan, atau pada lorong pelarutan. Meskipun demikian, airtanah tetap menjadi sumber air bersih (tawar) yang memungkinkan diambil dengan jumlah yang paling besar di dunia (Taniguchi dan Holman, 2010). Airtanah juga menjadi pemasok hampir 50\% dari total pemenuhan kebutuhan air minum manusia di seluruh dunia (WWAP, 2009; Treidel el al., 2011) dan memenuhi sekitar 
43\% kebutuhan irigasi pertanian di seluruh dunia (Sibert et al., 2010). Selain itu, pada wilayah arid dan semi arid, airtanah diperkirakan menyediakan $80 \%$ kebutuhan air bersih dari total kebutuhan air bersih di wilayah tersebut (Karamouz et al., 2011).

Perubahan lingkungan khususnya terkait dengan iklim diperkirakan lebih cepat dari siklus geologinya di masa lampau. Kondisi demikian diperkirakan akan menyebabkan banyak permasalahan terkait dengan berbagai aspek kehidupan manusia, di antaranya adalah aspek pemenuhan kebutuhan air bersih. Wilayah yang kemungkinan akan mengalami banyak dampak terkait hal tersebut adalah wilayah pesisir dan pulau-pulau kecil (Cahyadi dkk., 2015a). Indonesia dengan jumlah pulau kecil dan pulau sangat kecil yang banyak. Anggraini dan Cahyadi (2013) menyebutkan bahwa jumlah pulau di Indonesia dengan luas kurang dari 2.000 $\mathrm{km}^{2}$ atau disebut sebagai pualau kecil adalah 13.435 (99,77\% dari jumlah pulau di Indonesia).

Pulau kecil dan pulau sangat kecil memiliki karakteristik airtanah yang unik dan sangat berbeda dengan kondisi airtanah di pulau besar (Gilli et al., 2012; Cahyadi dan Tivianton, 2013; Cahyadi dkk., 2013). Karakteristik airtanah pulau kecil yang khas di antaranya adalah terbentuknya lensa airtanah, meskipun pada beberapa lokasi hal ini tidak ditemukan karena kondisi geologi yang tidak memungkinkan (Cahyadi, 2015). Misalnya terdapat batuan kedap air dan atau terdapatnya material penyusun pulau yang tidak seragam. Selain itu, pulau kecil memiliki karakteristik hidrolo berupa tangkapan air hujan yang relatif sempit, curah hujan yang lebih sedikit, serta terpengaruhi oleh adanya proses intrusi air laut (Custodio, 2005; Cahyadi, 2012; Cahyadi dkk., 2016).
Kerusakan sumberdaya airtanah di pulau kecil setidaknya dapat terjadi karena dua faktor, yakni faktor alami dan faktor non-alami. Kerusakan sumberdaya airtanah pada pulau kecil oleh faktor alami misalnya terjadinya intrusi air laut (Aris et al., 2013), evapotranspirasi yang terlalu tinggi, curah hujan yang menurun atau meningkat drastis, pengaruh tanaman seperti proses selective uptake, aktivitas vulkanisme dan gempabumi. Kerusakan sumberdaya airtanah di pulau kecil oleh proses nonalami misalnya pencemaran oleh limbah yang berasal dari aktivitas manusia (Howard, 2007), pemompaan airtanah berlebihan (Custodio, 2005; Cahyadi, 2012) atau pemompaan yang menyebabkan cross contamination dengan lapisan airtanah asin dan pengurangan resapan air karena perubahan penggunaan lahan yang menyebabkan sedikitnya resapan airtanah. Kerusakan sumberdaya airtanah ini menjadi isu yang harus mendapat perhatian khusus mengingat proses ini akan menyebabkan ketersediaan airtanah yang dapat dimanfaatkan semakin sedikit dan semakin memperbesar peluang terjadinya kelangkaan air bersih.

Airtanah secara alamiah akan memiliki sifat unik. Karakter ini di antaranya tercermin dari kondisi hidrogeokimianya. Hidrogeokimia didefinisikan sebagai ilmu yang membahas tentang komposisi dan karakteristik dari airtanah (Tikhomirov, 2016). Secara lebih luas pengertian tersebut meliputi komposisi dan karakteristik fisika, kimia, biologi dan karakter isotop dari airtanah. Cakupan hirogeokimia sendiri meliputi mendefinisikan waktu dan sumber dari imbuhan airtanah, mengestimasi seberapa lama airtanah berada di dalam akuifer, mengidentifikasi mineral yang membentuk akuifer dan dampaknya bagi komposisi dan karakteristik airtanah di dalamnya, menjelaskan bagaimana airtanah mengalami percampuran dan berinteraksi 
dengan batuan, serta mengevaluasi tipe proses (bio)geokimia yang terjadi selama perjalanan airtanah di dalam akuifer. Meskipun demikian, sangat sedikit kajian hidrogeokimia yang melakukan pembahasan secara menyeluruh terhadap cakupan tersebut karena berbagai keterbatasan.

Analisis hidrogeokimia dalam kajian pengelolaan lingkungan saat ini menjadi sangat penting (Šráček and Zeman, 2004). Aplikasi dalam pengelolaan lingkungan misalnya dapat digunakan untuk menganalisis proses lingkungan yang terjadi terhadap airtanah, menganalisis identifikasi intrusi air laut sekaligus menentukan derajat pengaruhnya terhadap airtanah (Cahyadi dkk., 2015b; Cahyadi dkk, 2015c), tipe batuan yang dominan berpengaruh terhadap kualitas air, kondisi wilayah imbuhan airtanah, lama tinggal airtanah dalam akuifer, evolusi hidrogeokimia airtanah (Agniy dan Cahyadi, 2015), sumber mineralisasi yang terjadi, tingkat kerusakan kualitas airtanah dan sumber pencemaran (Hem, 1970; Gilli et al., 2012; Hiscock and Bense, 2014). Hal ini akan sangat membantu dalam proses perencanaan pengelolaan sumberdaya airtanah di masa mendatang.

Penelitian ini mengambil kasus di Pulau Koral Panggang, Kabupaten Kepulauan Seribu, DKI Jakarta (Gambar 1). Pulau Koral Panggang merupakan salah satu pulau yang dihuni pertama di Kepualauan Seribu, sehingga banyak masyarakat menyebutnya sebagai "kampung". Luas pulau ini sekitar 9 hektar. Meskipun tergolong sangat kecil, jumlah penduduk pulau ini termasuk yang terbanyak di antara pulau lainnya yakni sekitar 4.000 jiwa pada tahun 2011. Hal ini menyebabkan kondisi penggunaan lahan di Pulau Koral Panggang didominasi oleh permukiman (Gambar 2). Berdasarkan kondisi pulau yang sangat kecil, jumlah penduduk yang sangat banyak, serta penutup lahan yang didominasi oleh lahan terbangun (Anggraini dan Cahyadi, 2013), maka kajian airtanah yang masih menjadi sumber air bersih di pulau ini perlu dikaji. Oleh karena itu, maka penelitian ini bertujuan untuk (1) menentukan tipe atau fasies hidrogeokimia airtanah di Pulau Koral Panggang, dan (2) menganalisis evolusi hidrogeokimia airtanah di Pulau Koral Panggang.

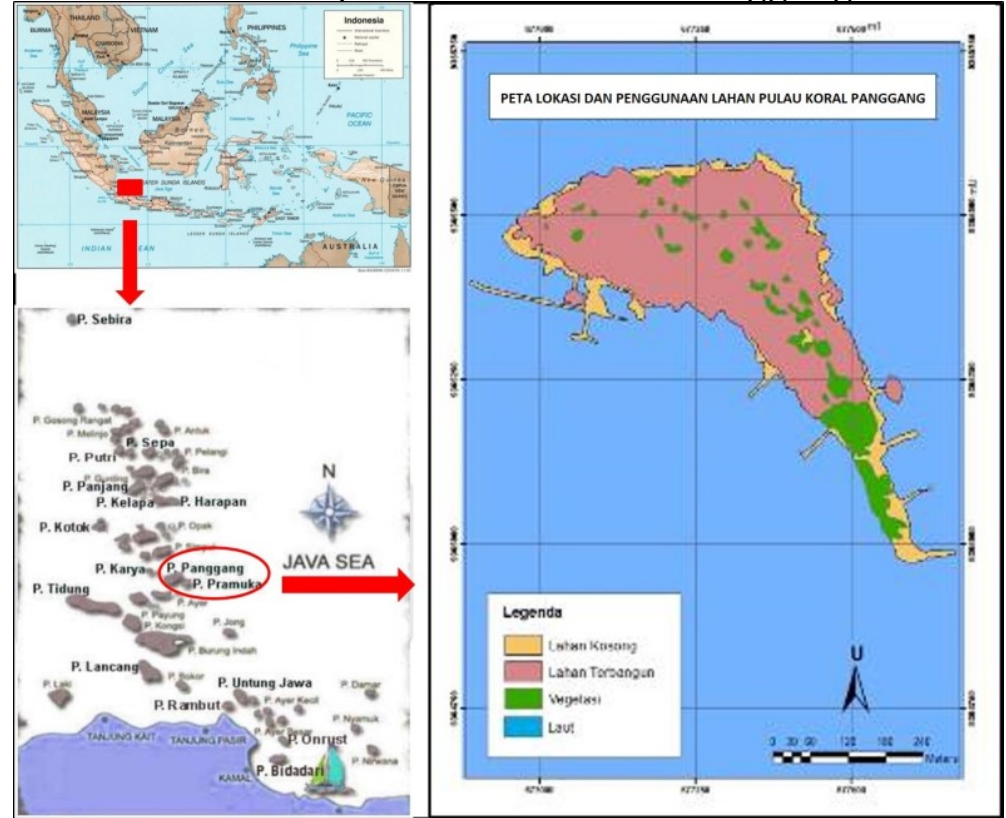

Gambar 1. Peta Lokasi Pulau Panggang, Kabupaten Kepualauan Seribu, DKI Jakarta 


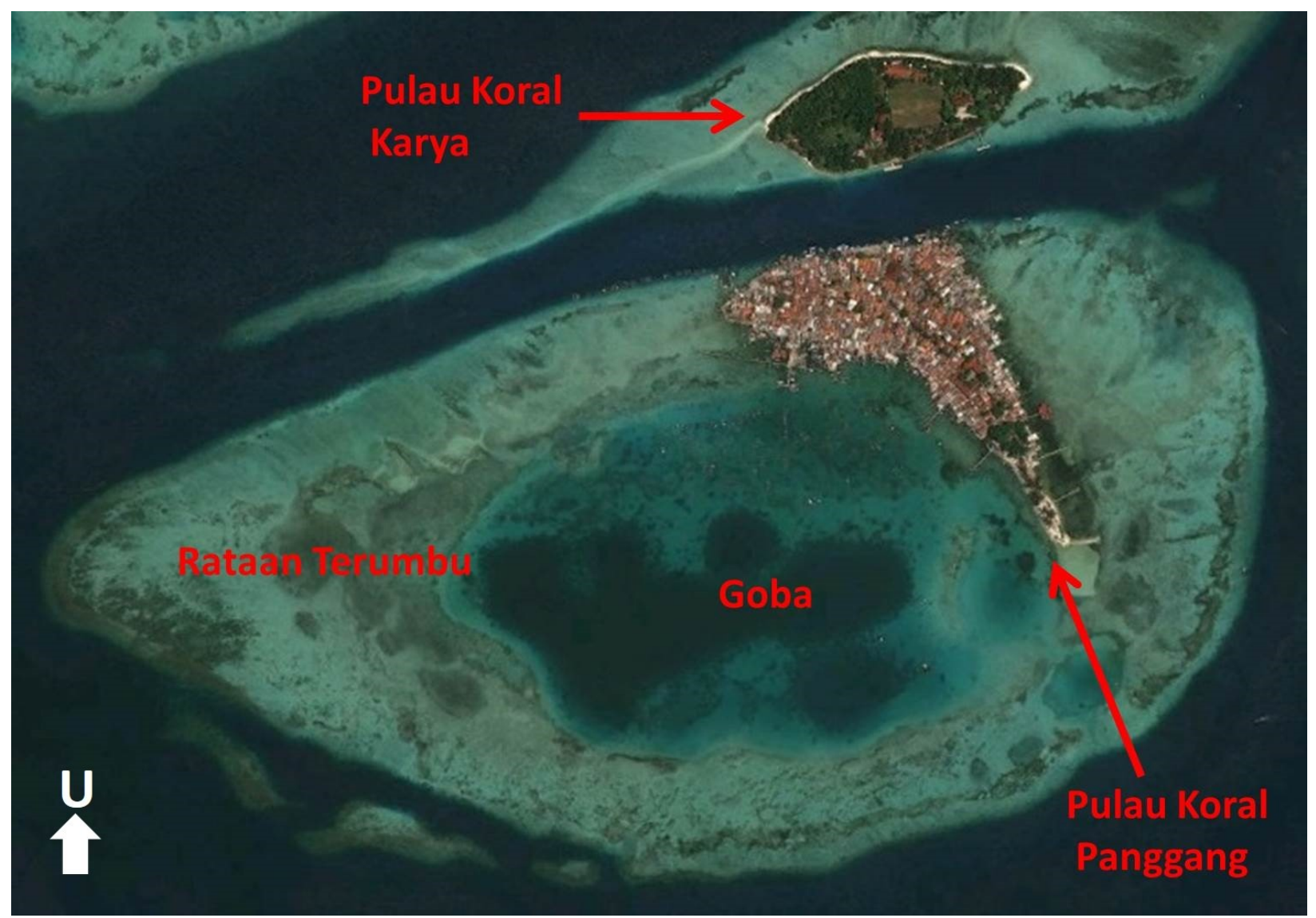

Gambar 2. Citra Satelit Ikonos Tahun 2008 yang Menunjukkan Lahan Terbangun yang Sangat Dominan

\section{METODE PENELITIAN}

Sampel airtanah yang digunakan dalam penelitian ini berjumlah 8 sampel. Sampel diambil pada sumur gali milik penduduk yang secara spasial mewakili bagian pinggir pulau dan bagian tengah pulau (Gambar 3). Hal ini agar hasil penelitian dapat memberikan gambaran spasial dari airtanah yang kemungkinan juga terpengaruh oleh intrusi air laut. Pengambilan sampel airtanah sebanyak 1 liter air untuk masingmasing titik sampel dan kemudian dianalisis di Laboratorium Hidrologi dan Klimatologi Lilngkungan, Fakultas Geografi Universitas Gadjah Mada di Yogyakarta.

Unsur yang dianalisis dalam penelitian ini meliputi unsur mayor dalam airtanah. Unsur-unsur yang dianalisis meliputi Kalsium $\left(\mathrm{Ca}^{2+}\right)$, Natrium $\left(\mathrm{Na}^{+}\right)$, Magnesium $\left(\mathrm{Mg}^{2+}\right), \quad$ Kalium $\left(\mathrm{K}^{+}\right), \quad$ Klorida $(\mathrm{Cl})$,
Bikarbonat $\left(\mathrm{HCO}_{3}^{-}\right)$dan Sulfat $\left(\mathrm{SO}_{4}^{-}\right)$. Analisis hasil uji laboratorium juga dilakukan dengan pengecekan keseimbangan ion. Apabila hasil analisis keseimbangan ion memiliki tingkat kesalahan lebih dari 10\%, maka analisis uji laboratorium dilakukan pengulangan. Hasil analisis dari sampel airtanah kemudian dianalisis dengan menggunakan diagram stiff untuk menentukan tipe hidrogeokimia atau fasies hidrogeokimia dari airtanah. Diagram stiff akan menunjukkan ion-ion (positif dan negatif) yang dominan dalam airtanah, sehingga tipe fasiesnya dapat ditentukan. Analisis evolusi dari hidrogeokimia airtanah yangn terjadi dilakukan dengan diagram piper. Berdasarkan diagram ini, akan diketahui tipe hidrogeokimia awal dan tipe hidrogeokimia saat ini. Dengan demikian, 
maka evolusi hidrogeokimia airtanah yang terjadi dapat ditentukan.

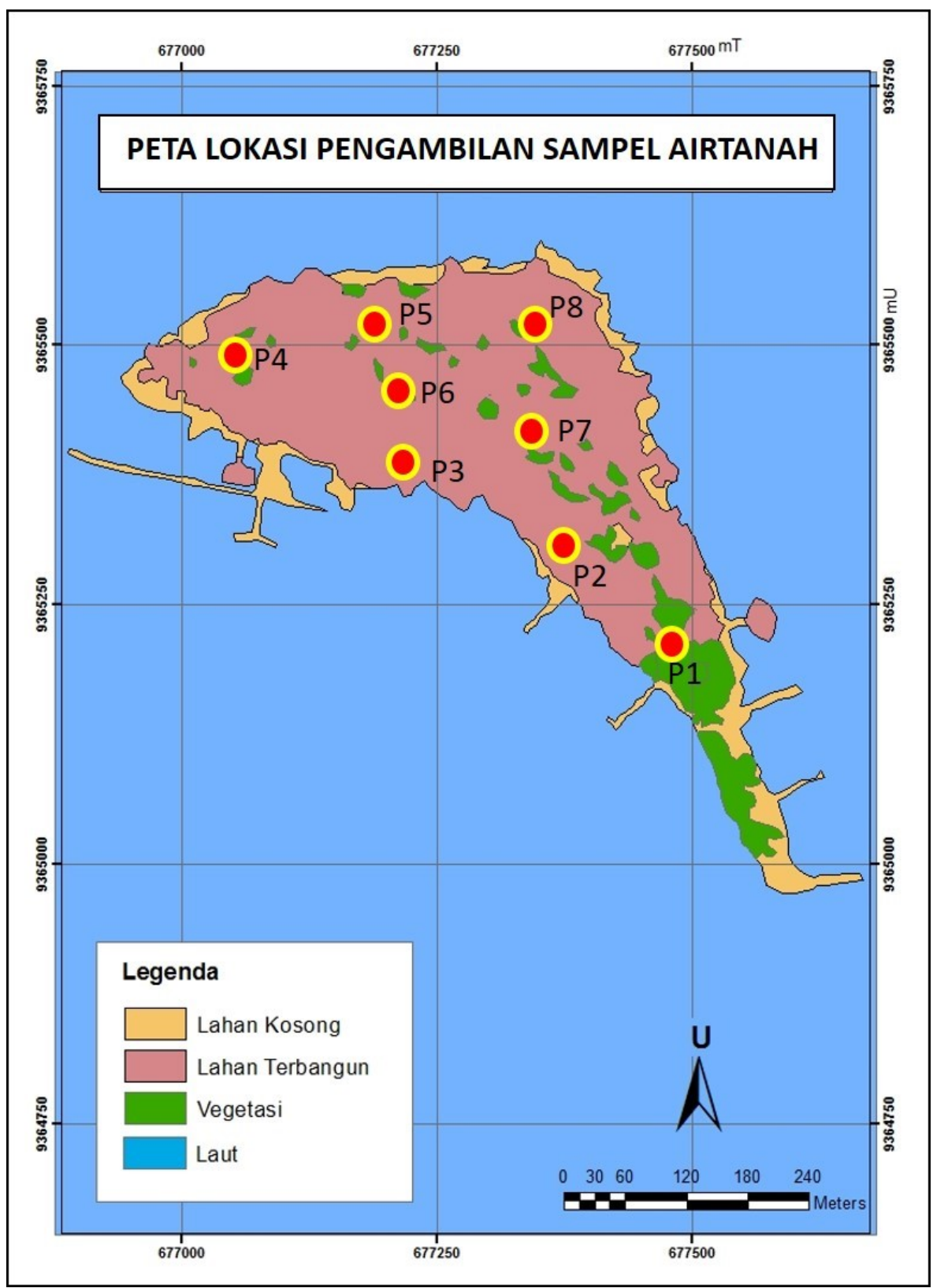

Gambar 3. Peta Lokasi Pengambilan Sampel Airtanah di Pulau Koral Panggang

HASIL DAN PEMBAHASAN

Analisis Tipe Air atau Analisis Fasies Hidrokimia

Hasil analisis laboratorium terhadap sampel airtanah di Pulau Koral Panggang disajikan pada Tabel 1. Kandungan unsur dalam airtanah yang nampak pada Tabel 1 masih dalam satuan milligram per liter (mg/l), sehingga secara langsung tidak dapat dibandingkan. Pembandingan hanya bias dilakukan dengan mengubah satuan menjadi miliequvalen per liter (meq/l). Namun demikian, kandungan unsur dalam airtanah dapat dianalisis dengan membandingkan nilai atau jumlah unsur yang biasa terdapat dalam airtanah tawar. 
Nampak pada Tabel 1 bahwa unsur dengan nilai yang lebih besar dari kondisi airtanah tawar adalah nilai Kalium, Magnesium dan Klorida. Kenaikan ketiga unsur tersebut kemungkinan disebabkan adanya pengaruh intrusi air laut atau percampuran dengan air laut (Hiscock and Bense, 2014).

Kandungan unsur dalam airtanah sangat terkait dengan genesis pembentukan akuifer, lingkungan pengendapan saat akuifer terbentuk, komposisi penyusun akuifer, proses yang terjadi selama berada di akuifer, dan lama tingggal airtanah dalam akuuifer. Pengaruh kondisi akuifer pada airtanah di Pulau Koral Panggang masih nampak dari cukup tingginya kandungan Kalsium dan Bikarbonat. Kedua unsur ini dipengaruhi kondisi akuifer yang tersusun atas material bioklastik gamping yang terendapkan pada masa kuarter.

Gambar 4 menunjukkan diagram stiff dari sampel airtanah di Pulau Koral Panggang. Penggambaran dalam diagram stiff menunjukkan perbandingan masingmasing unsur dalam satuan meq/l. Banyaknya ion klorida pada diagram stiff di semua sampel airtanah menunjukkan adanya pengaruh dari intrusi air laut seperti yang diduga sebelumnya. Hal ini karena kandungan klorida dalam airtanah sangat jarang sekali dihasilkan dari batuan, sehingga keterdapatannya di dalam airtanah hanya terkait dengan adanya

Tabel 1. Kandungan Ion Mayor dalam Airtanah di Pulau Koral Panggang(mg/l)

\begin{tabular}{|l|c|c|c|c|c|c|c|}
\hline No. & $\mathbf{K}^{+}$ & $\mathbf{N a}^{+}$ & $\mathbf{C a}^{2+}$ & $\mathbf{M g}^{2+}$ & $\mathbf{C l}^{-}$ & $\mathbf{H C O}_{3}$ & $\mathbf{S O}_{4^{-}}$ \\
\hline P1. & 59,53 & 495,80 & 370,00 & 399,00 & $2.680,00$ & 380,00 & 62,07 \\
\hline P2. & 60,67 & 581,30 & 300,00 & 832,00 & $4.180,00$ & 192,00 & 78,83 \\
\hline P3. & 58,69 & 543,00 & 280,00 & 750,00 & $3.890,00$ & 332,00 & 61,86 \\
\hline P4. & 60,00 & 422,80 & 350,00 & 796,00 & $3.910,00$ & 324,00 & 68,51 \\
\hline P5. & 60,00 & 267,40 & 400,00 & 881,00 & $3.540,00$ & 268,00 & 65,93 \\
\hline P6. & 60,65 & 467,20 & 320,00 & 700,00 & $3.130,00$ & 236,00 & 70,89 \\
\hline P7. & 58,17 & 537,20 & 230,00 & 587,00 & $3.200,00$ & 228,00 & 25,76 \\
\hline P8. & 58,15 & 424,00 & 280,00 & 556,00 & $3.200,00$ & 228,00 & 6,68 \\
\hline
\end{tabular}

Sumber: Hasil Analisis Laboratorium Hidrologi dan Klimatologi Lingkungan, Fakultas Geografi UGM pencemaran dan pengaruh dari air laut (Younger, 2007). Kandungan magnesium pada airtanah yang tipe awalnya didominasi oleh kalsium karbonat menunjukkan airtanah telah menuju ke asin sampai pada tahapan payau (Aris et al., 2013). Melihat tingginya kandungan natrium yang tinggi, dan hampir menyamai kandungan magnesium dalam satuan meq/l, maka kemungkinan airtanah terdampak intrusi air laut sudah parah. Kondisi tersebut karena penggeseran ion magnesium oleh ion natrium dan kalium merupakan tahapan evolusi kimia yang kedua dari tipe airtanah kalsium karbonat (Aris dkk, 2007) seperti yang seharusnya terdapat di Pulau Koral Panggang.

Analisis tipe hidrokimia airtanah dalam penelitian ini dilakukan dengan menyajikan data kandungan ion mayor airtanah hasil analisis laboratorium dalam diagram stiff. Hasil analisis diagram Stiff yang telah disajikan dalam Gambar 4 menunjukkan bahwa tipe kation yang dominan adalah magnesium, sedangkan tipe anion yang dominan adalah Klorida. Berdasarkan hal tersebut, maka tipe airtanah di Pulau Koral Panggang adalah $\mathrm{MgCl}_{2}$. Tipe air ini menurut Younger (2007) dan Aris et al., 2013) menunjukkan tipe airtanah payau sampai dengan asin sebagai akibat dari pengaruh intrusi air laut. 


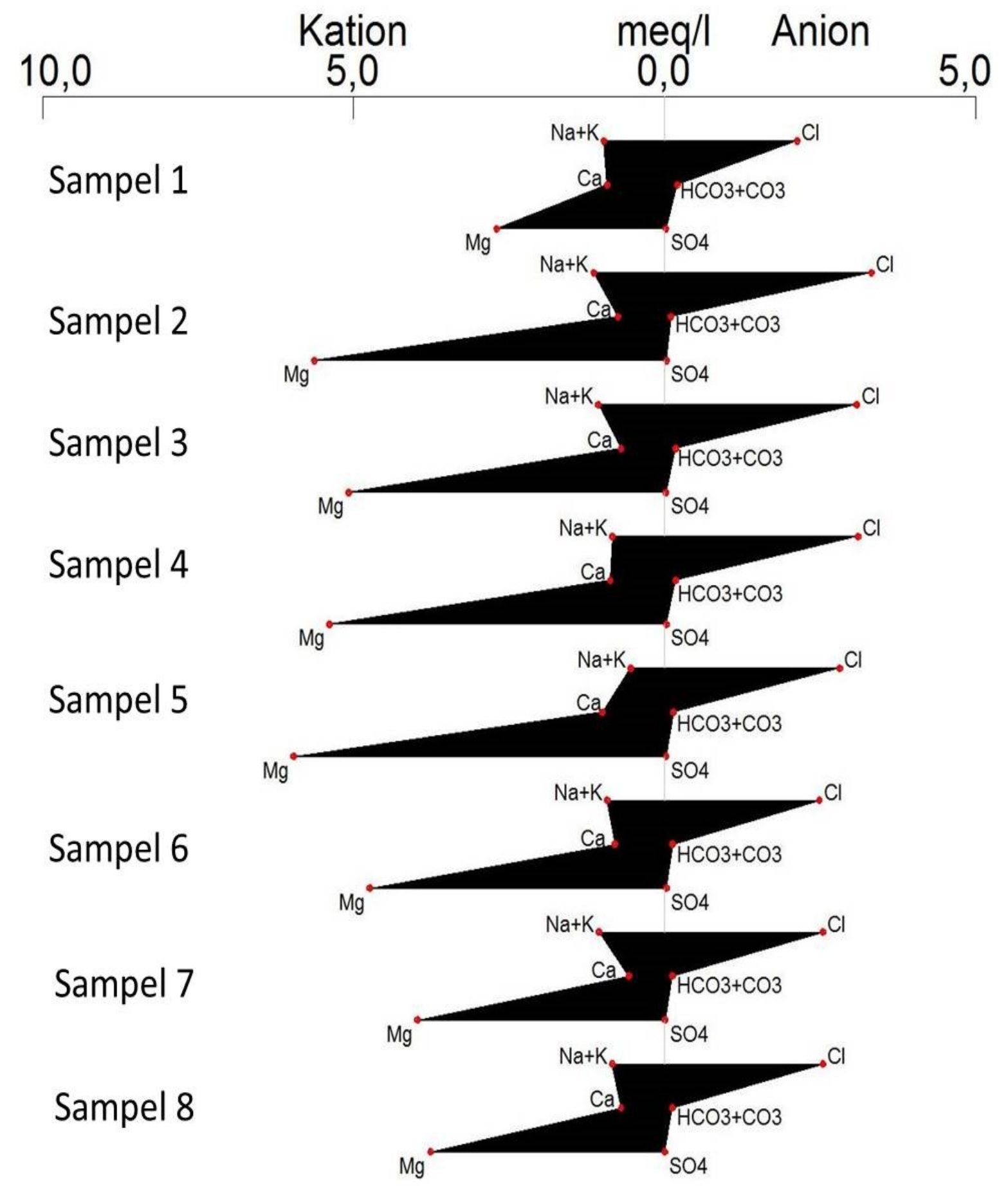

Gambar 4. Diagram Stiff Kandungan Ion Mayor dalam Airtanah di Pulau Koral Panggang

Analisis Evolusi Hidrokimia

Analisis evolusi hidrokimia airtanah dilakukan dengan menyajikan data kandungan ion mayor dalam airtanah di Pulau Koral Panggang dengan menggunakan diagram trilinear atau 
diagram piper (Gambar 5.). Berdasarkan hasil penyajian tersebut, diketahui bahwa tipe kation dominan pada airtanah di Pulau Koral Panggang adalah tipe $\mathrm{C}$ atau tipe Magnesium, sedangkan untuk anion tipe ion mayor adalah tipe $\mathrm{F}$ atau Klorida. Hal ini berarti bahwa secara hidrogeokimia, terjadi perubahan tipe air dari $\mathrm{Ca}^{2+}-\mathrm{HCO}_{3}$ atau $\mathrm{CaCO}_{3}$ menjadi $\mathrm{Mg}^{2+}-\mathrm{Cl}^{-}$atau $\mathrm{MgCl}_{2}$. Perubahan ini menurut Aris et al. (2013) adalah perubahan pada tingkat kedua pada akuifer berbatuan karbonat yang terpengaruh intrusi air laut. Apabila intrusi air laut terus terjadi, maka tipe hidrokimia airtanah akan berubah menjadi Natrium/Kalium Klorida $(\mathrm{NaCl}$ atau $\mathrm{KCl})$ (Hiscock and Bense, 2014).

Evolusi hidrogeokimia yang dipengaruhi oleh proses intrusi air laut harus menjadi perhatian khusus dalam pengelolaan airtanah di Pulau Koral Panggang. Mempertahankan kondisi resapan dengan meresapkan air hujan yang jatuh di atas dan lahan terbangun lain menjadi salah satu kunci keberlanjutan airtanah dan mencegah semakin jauhnya dampak intrusi air laut. Selain itu, pemenuhan kebutuhan air deri sumber yang lain seperti desalinasi dan pembuatan sumur artesis harus menjadi rencana jangka panjang. Rencana jangka pendek dapat dilakukan pembuatan sarana reverse osmosis dan pengambilan air dari Pulau Jawa dengan menjamin keberadaan sarana transportasi yang mendukung. Pembuatan sumur artesis dapat dilakukan dengan melakukan kajian lebih lanjut terkait dengan akuifer di lokasi kajian. Pembuatan sumur artesis dimasa penjajahan Belanda di Pulau Koral Cipir dan Onrust merupakan contoh keberhasilan pembuatan sumur artesis yang dibuat dengan pengeboran dalam.

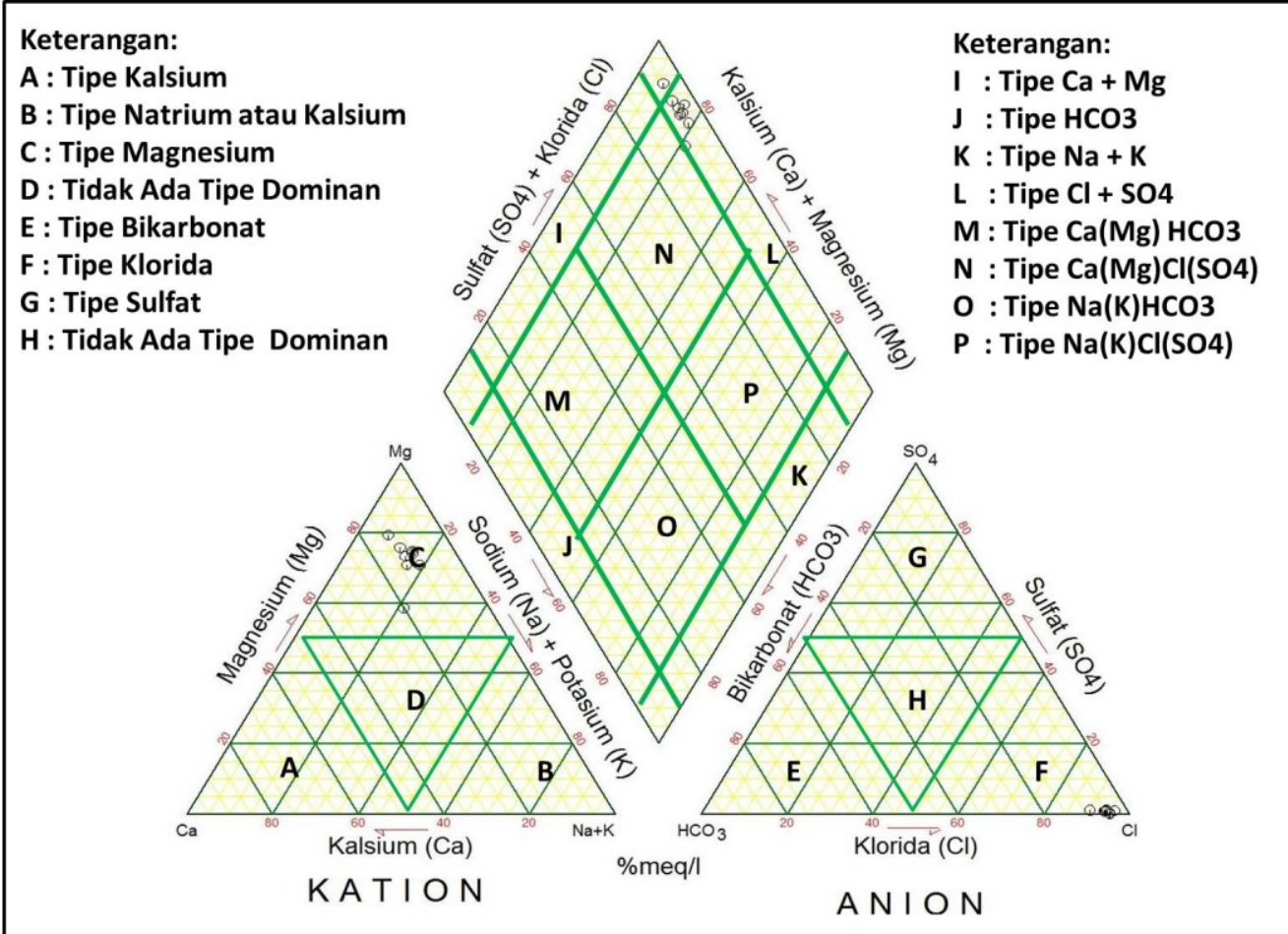

Gambar 5. Diagram Piper Karakteristik Hidrokimia Airtanah di Pulau Koral Panggang 


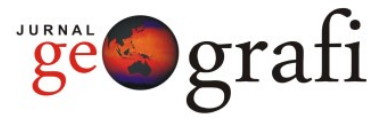

\section{KESIMPULAN}

Hasil analisis diagram stiff menunjukkan bahwa keseluruhan sampel airtanah memiliki tipe fasies hidrokimia airtanah di Pulau Koral Panggang adalah $\mathrm{MgCl}_{2}$. Tipe hidrogeokimia ini berdasarkan hasil analisis diagram piper mengalami evolusi hidrokimia dari $\mathrm{CaCO}_{3}$ menjadi $\mathrm{MgCl}_{2}$. Evolusi yang terjadi pada hidrogeokimia airtanah ini menunjukkan adanya pengaruh dari intrusi air laut. Proses intrusi air laut ini kemungkinan terjadi karena tingginya tingkat pemanfaatan airtanah, namun sangat sedikit jumlah imbuhan airtanah karena penggunaan lahan terbangun sekitar $74 \%$ luas wilayah.

\section{UCAPAN TERIMAKASIH}

Terimakasih kami sampaikan kepada Hendy Fatchurohma, S.Si. dari Magister Pengelolaan Pesisir dan Daerah Aliran Sungai (MPPDAS) Fakultas Geografi Universitas Gadjah Mada yang telah membantu dalam pengambilan data lapangan. Kami juga menyampaikan terima kasih kepada pengurus MPPDAS yang telah memberikan banyak bantuan kepada penulis selama melaksanakan penelitian ini.

\section{DAFTAR PUSTAKA}

Agniy, R.F. dan Cahyadi, A. 2015. Analisis Evolusi Hidrogeokimia Airtanah di Sebagian Mataair Karst Kabupaten Rembang Bagian Selatan. Prosiding Seminar Nasional Innovation in Environmental Management. Semarang: Program Pascasarjana Universitas Diponegoro.

Anggraini, D.F. dan Cahyadi, A. 2013. Analisis Perubahan Penggunaan Lahan dan Pola Adaptasi Masyarakat Terhadap Keterbatasan Lahan di Pulau Panggang
Available at http://iurnal.unimed.ac.id/2012/index.php/geo e-ISSN: 2549-7057 | p-ISSN: 2085-8167

Kepulauan Seribu DKI Jakarta. Jurnal Geografi, 11: 123-129.

Aris, A.Z.; Praveena, S.M. dan Isa, N.M. 2013. Groundwater Composition and Geochemical Controls in Small Tropical Island of Malaysia: A Comparative Study. dalam Wetzelhuetter, C. 2013. Groundwater in The Coastal Zones of AsiaPacific. Dordrecht: Springer.

Cahyadi, A. 2012. Permasalahan Sumberdaya Air di Pulau Karang Sangat Kecil (Studi Kasus di Pulau Pramuka, Kabupaten Kepulauan Seribu, DKI Jakarta). Prosiding Seminar Nasional Pengelolaan Sumberdaya Alam dan Lingkungan. Semarang: Program Studi Ilmu Lingkungan Universitas Diponegoro.

Cahyadi, A.; Hidayat, W. dan Wulandari. 2013. Adaptasi Masyarakat Terhadap Keterbatasan Sumberdaya Air di Pulau Pramuka, Kepulauan Seribu, DKI Jakarta. Jurnal Penelitian Kesejahteraan Sosial, 12 (2): 207 - 213.

Cahyadi, A. dan Tivianto, T.A. 2013. Persepsi Masyarakat Terhadap Pemanenan Air Hujan dan Dampaknya Terhadap Ketahanan Sumberdaya Air di Pulau Pramuka, Kepulauan Seribu, DKI Jakarta. dalam Marfai, M.A. dan Widyastuti, M. 2013. Pengelolaan Lingkungan Zamrud Khatulistiwa. Yogyakarta: Buku Pintal.

Cahyadi, A. 2015. Analisis Potensi Sumberdaya Air Pulau Koral Sangat Kecil (Studi Kasus di Pulau Koral Pramuka, Kabupaten Kepulauan Seribu, DKI Jakarta). Tesis. Yogyakarta: Magister Perencanaan Pengelolaan Pesisir dan Daerah Aliran Sungai (MPPDAS), Fakultas Geografi, Universitas Gadjah Mada.

Cahyadi, A.; Marfai, M.A.; Tivianton, T.A.; Wulandari dan Hidayat, W. 2015a. Menyelamatkan Masa Depan Pulau- 
Pulau Kecil Indonesia. Prosiding Sarasehan Nasional Geografi Tahun 2013. Yogyakarta: Fakultas Geografi Universitas Gadjah Mada.

Cahyadi, A.; Agniy, R.F. dan Suhana, S.N. 2015b. Karakterisasi Hidrogeokimia Airtanah untuk Analisis Genesis Airtanah di Pulau Koral Sangat Kecil. Prosiding Seminar Nasional Ke-1 dalam Pengelolaan Pesisir dan Daerah Aliran Sungai. Yogyakarta: Magister Perencanaan Pengelolaan Pesisir dan Daerah Aliran Sungai, Fakultas Geografi, Universitas Gadjah Mada.

Cahyadi, A.; Adji, T.N. dan Marfai, M.A. 2015c. Analisis Evolusi Hidrogeokimia Airtanah di Pulau Koral Pramuka, Kepulauan Seribu. Prosiding Seminar Nasional Geografi. Surakarta: Universitas Muhammadiyah Surakarta.

Cahyadi, A.; Adji, T.N. dan Marfai, M.A. 2016. Uji Akurasi Aplikasi Electromagnetic Very Low Frequency (EM $V L F)$ untuk Analisis Potensi Airtanah di Pulau Sangat Kecil. Prosiding Seminar Nasional Ke-2 dalam Pengelolaan Pesisir dan Daerah Aliran Sungai. Yogyakarta: Magister Perencanaan Pengelolaan Pesisir dan Daerah Aliran Sungai, Fakultas Geografi, Universitas Gadjah Mada.

Custodio, E. 2005. Coastal Aquifer as Important Natural Hydrogeological Structures. dalam Bocanegra, E.M.; Hernandez, M.A. dan Usunoff, E. (eds) 2005. Groundwater and Human Development. Leiden: A.A. Balkema Publisher.

Gilli, E.; Mangan, C. dan Mudry, J. 2012. Hydrogeology: Objectives, Methods, Applications, diterjemahkan dari Bahasa
Perancis oleh Chloe Fandel. Boca Raton: CRC Press.

Hem, J.D., 1970. Study and Interpretation of the Chemical Characteristic of Natural Water. United State Government Printing Office. Washington D.C.

Hiscock, K.M. dan Bense, V.F. 2014. Hydrogeology: Principles and Practice, Second Edition. Chichester: John Wiley and Sons Ltd.

Karamouz, M.; Ahmadi, A. dan Akhbari, M. 2011. Groundwater Hydrology: Engineering, Planning and Management. Boca Raton: CRC Press.

Sen, Z. 2015. Practical and Applied Hydrogeology. Waltham, UK: Elsevier.

Siebert, S.; Burke, J.; Faures, J.M.; Frenken, K.; Hoogeven, J.; Dört, P. dan Portmann, F.T. 2010. Groundwater Use for Irrigation- A Global Inventory. Hydrology and Earth System Sciences, 14: 1864 - 1880.

Šráček, O. dan Zeman, J. 2004. Introduction to Environmental Hydrogeochemistry. Brno: Faculty of Science, Masaryk University.

Tanuguchi, M. dan Holman, I.P. 2010. Groundwater Response to Changing Climate. Boca Raton: CRC Press.

Treidel, H.; Martin-Bordes, J.L. dan Gurdak, J.J. 2011. Climate Change Effects on Groundwater Resources: A Global Syntesis of Findings and Recommendations. Boca raton: CRC Press.

WWAP (World Water Assessment Programme). 2009. The United Nations Worid Water Development Report 3: Water in a Changing World. Paris: UNESCO Publishing.

Younger, P.L. 2007. Groundwater in the Environment. Oxford, UK: Blackwell Publishing. 